\title{
USE OF LIFESTYLE SEGMENTATION FOR ASSESSING CONSUMERS' ATTITUDES AND BEHAVIORAL OUTCOMES TOWARDS MOBILE ADVERTISING
}

\section{SEGMENTACIJA TEMELJEM ŽIVOTNOG STILA RADI PROCJENE STAVOVA POTROŠAČA I ISHODA PONAŠANJA PREMA MOBILNOM OGLAŠAVANJU}

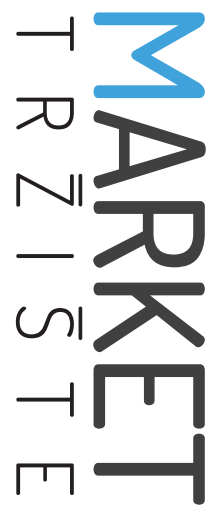

\author{
Market-Tržište \\ Vol. 30, No. 2, 2018, pp. 213-229 \\ UDK 658.89:654.165:659.1 \\ DOI http://dx.doi.org/10.22598/mt/2018.30.2.213 \\ Preliminary communication
}

\begin{abstract}
Nauman Zaheera, Mihael Kline ${ }^{b}$
a) University of Ljubljana Faculty of Social Sciences, Kardeljeva ploščad 5, 1000 Ljubljana, SLOVENIA, e-mail: itsnaumanzaheer@hotmail.com

b) University of Ljubljana Faculty of Social Sciences, Kardeljeva ploščad 5, 1000 Ljubljana, SLOVENIA, e-mail: mihael. kline@fdv.uni-lj.si
\end{abstract}

\begin{abstract}
Purpose - Mobile communication has become an integral part of people's lives in recent times. Consumers' purchasing behaviors have been found to be influenced by their attitudes towards mobile advertising. This study explored the usability of lifestyle segmentation to find differences among consumers and assessed the relationship between consumers' attitudes toward mobile advertising.
\end{abstract}

Design/Methodology/Approach - The study is based on primary data collected through a survey questionnaire on a consumer sample in Pakistan. The study surveyed 166 respondents and categorized them into three different lifestyle groups: self-indulgents, experiencers, and traditionalists. Factor analysis and cluster analysis techniques were applied on the data to identify lifestyle segments, whereas a one-way ANOVA test was used to find significant lifestyle differences among mobile device users as regards their attitudes and behaviors towards mobile advertising.

Findings and implications - Significant statistical differences were found among lifestyle segments in terms

\section{Sažetak}

Svrha - Mobilna je komunikacija postala sastavni dio života ljudi u novije vrijeme. Ustanovljeno je da su kupovna ponašanja potrošača pod utjecajem njihovih stavova prema mobilnom oglašavanju. Istraživanje je ispitivalo iskoristivost segmentacije na temelju životnoga stila za pronalaženje razlika među potrošačima i procjenu odnosa između stavova potrošača prema mobilnom oglašavanju.

Metodološki pristup - Istraživanje se temelji na primarnim podatcima prikupljenim putem anketnih upitnika na uzorku potrošača iz Pakistana. Ono je obuhvatilo 166 ispitanika i razvrstalo ih u tri različite skupine prema životnom stilu: lagodni, iskustveni i tradicionalni. Primijenjene su faktorska i klasterska analiza kako bi se identificirali segmenti na temelju životnoga stila, a analiza varijance korištena je za pronalaženje značajnih razlika među korisnicima mobilnih uređaja prema njihovom životnom stilu, u odnosu na njihove stavove i ponašanja prema mobilnom oglašavanju.

Rezultati i implikacije - Značajne statističke razlike pronađene su među segmentima životnoga stila u od- 
of attitudes and behavioral outcomes towards mobile advertising. The demographic variables were found to be insignificant for finding attitudinal and behavioral differences among consumers. The relationship between attitudes and behaviors was also found to be positive. Marketers can design their promotional campaigns more effectively by using a lifestyle segmentation approach.

Limitations - The scope of the study is limited, as it is a single-market investigation, and its explanatory power is low because of the sample size.

Originality - The applicability of lifestyle segmentation in comparison to demographic variables to find attitudinal and behavioral differences towards mobile advertising had not been done before.

Keywords - mobile advertising, attitudes, consumer behavior, lifestyle segmentation, behavioral outcomes nosu na stavove i ishode ponašanja prema mobilnom oglašavanju. Utvrđeno je da su demografske varijable beznačajne za pronalaženje razlika u stavovima i ponašanju među potrošačima. Ustanovljeno da je odnos između stavova i ponašanja pozitivan. Marketinški stručnjaci mogu učinkovitije oblikovati svoje promotivne kampanje korištenjem segmentacije temeljem životnog stila.

Ograničenja - Opseg istraživanja je ograničen jer je istraženo samo jedno tržište. Objašnjavajući je potencijal istraživanja nizak zbog veličine uzorka.

Doprinos - Primjenjivost segmentacije temeljem životnog stila u usporedbi s demografskim varijablama za pronalaženje razlika u stavovima i ponašanju prema mobilnom oglašavanju nije do sada ispitivana.

Ključne riječi - mobilno oglašavanje, stavovi, ponašanje potrošača, segmentacija temeljem životnoga stila, ishodi ponašanja 


\section{INTRODUCTION}

Wireless or mobile communication has become an integral part of people's lives since the first wireless transmission of radio waves by Guglielmo Marconi in 1895. The world has witnessed tremendous technological advancements in wireless communication in the shape of mobile devices. This has not only enabled the user to communicate with others but also has presented various new ways for marketers to deliver their messages in numerous innovative ways. According to the online statistical portal Statista (2016), there were around 4.61 billion mobile phone users around the world in 2016. The practices of mobile advertising are growing at a rapid pace because of the high penetration rate of mobile phones among consumers worldwide.

Sharma, Herzog and Melfi (2008) highlight four unique elements of mobile devices which make them better advertising media than other conventional media of advertising. First, mobile devices have become a personal fashion statement for users. Moreover, mobile devices are very high in numbers throughout the world. Statista (2016) highlighted that the number of mobile users in the United States had exceeded the number of subscribers to Internet services. Furthermore, as mobile devices became symbols of users' social status, mobile companies and service providers were urged to enhance the level of advancements in mobile technology (Jun \& Lee, 2007). This has opened new horizons for marketers in terms of the ways in which their products are advertised. Secondly, the most important characteristic of mobile devices is associated with their mobility; as mobile devices can be carried around almost all the time, their users are accessible for marketers at any time of the day. Users do not need to turn on their TV or radio to be exposed to advertising. Recent advancements in mobile technology have enabled marketers to trace the geographical locations of consumers and, based on that data, to send them specific information and advertising material.
Third, different associated features of mobile devices, such as touchscreens, cameras, and audio/video multimedia, provide unique input experience to consumers, which consequently increases consumers' participation in persuasive communication. Advertisers have capitalized on these features for their benefit as well in the shape of advertising through bar codes. Furthermore, marketers have made the process of purchasing very easy for consumers by offering services including those that enable consumers to pay for their purchases through mobile phone applications. This way of business, known as mobile commerce, is quite famous especially in Asian countries, such as Japan, Korea, Singapore, and China.

The crucial nature of attitude and its impact on advertising has been researched in various studies (see, Petrovici, Marinov, Paliwoda \& Marinova, 2013). Petrovici and others (2013) found that positive or negative attitudes towards advertising can affect the effectiveness of advertising. Mobile advertising has undergone tremendous growth in recent years, and several researchers have worked on examining mobile device users' attitudes towards mobile advertising (Barutçu, 2007; Ünal, Ercis \& Keser, 2011). Most of the previous studies (Korgaonkar, Petrescu \& Karson, 2015; Parreño, Sanz-Blas, Ruiz-Mafé \& Aldás-Manzano, 2013) treated mobile device users as a homogeneous group and did not take intra-group differences into consideration. Therefore, attitudinal and behavioral differences were not detected. Previous literature on consumer behavior has regarded lifestyle as an important concept for the study of consumers' purchasing decisions (Park, Kim, Ki \& Moon, 2001). As the number of mobile device users grows, more lifestyle and demographic diversity is found among those users (Park et al., 2001). Hence, it is important for researchers and advertisers to better understand the diversity of mobile device users for their attitudes and behaviors towards mobile advertising. Previous studies (Barutçu, 2007; Saadeghvaziri \& Hosseini, 2011) mainly used demographic variables such as age, 
gender, educational, and income level to classify mobile device users. However, numerous researchers, including González and Bello (2002) and Yang (2004) have pointed out the limited nature of demographic variables in studying consumers' attitudinal and behavioral patterns. Even though various studies have highlighted the importance of lifestyle segmentation, only a few researchers have investigated consumers' attitudes on the basis of lifestyle segmentation. Therefore, keeping in view the popularity of mobile advertising, the current study examined the relationships between consumers' lifestyles, attitudes, and behaviors towards mobile advertising.

\section{LITERATURE REVIEW}

\subsection{Attitude towards mobile advertising}

Attitude is considered one of the important concepts in research on marketing, advertising, and information systems. Attitude has been defined in various ways by different researchers. Fishbein and Raven (1962) defined attitude as "a learned predisposition of individuals", while Kotler and Keller (2015) defined the concept of attitude as a "person's favorable or unfavorable evaluations, emotions, and action tendencies towards some object or idea". For quite some time, researchers have been exploring the concept of attitude in various fields of study, such as sociology, psychology, and marketing. Furthermore, there is a considerable amount of literature dealing with consumers' attitudes towards advertising in general and Internet/mobile advertising in particular. Ducoffe (1996) argued that attitude was proven to be a crucial construct for information systems research, as the Technology Acceptance Model predicted some crucial constructs, such as perceived ease of use, perceived usefulness, intentions, and attitudes. Numerous studies (Barutçu, 2007; Fazio, 1990; Glasman \& Albarracín, 2006; Terry \& Hogg, 1996) have confirmed the relationship between consumers' attitudes and their behavioral intentions.
An increase in the rate of penetration of mobile phones over the past decade has created significant opportunities for marketers, advertisers, and mobile application developers. As an extension of the Internet environment, mobile/ wireless services have allowed users to have interactive access to web-based content and applications by using various mobile devices, such as smartphones, tablets, personal digital assistants (PDAs), portable media players, and smartwatches. Many features are common to both Internet advertising and mobile advertising, as both are used to deliver promotional messages in the form of digital texts, images, voices, and videos thanks to having highly personalized and responsive capabilities (Tsang, Ho \& Liang, 2004). Consumer behavior variables are commonly employed by various researchers (Tsang et al., 2004) in their efforts to study mobile advertising. Moreover, mobile advertising researchers have followed the traditions of Internet advertising research in order to explore consumers' attitudes (Ünal et al., 2011), behavioral intentions (Merisavo et al., 2007) and assess the effectiveness of mobile advertising (Merisavo, Vesanen, Arponen, Kajalo \& Raulas, 2006).

Okazaki, Molina and Hirose (2012) argued that mobile advertising is perceived to be disturbing and intrusive by most consumers. For this reason, consumers tend to apply various mechanical and behavioral solutions to avoid such advertisements (Johnson, 2013). Two different opinions can be found in related literature, and Okazaki and others (2012) suggested that mobile advertising should be less intrusive. Meanwhile, Edwards, Li and Lee (2002) posited that forced exposure is the most effective way of increasing the level of consumer awareness. The use of any behavioral, cognitive, or mechanical methods to avoid mobile advertising on the part of users is highly dependent upon attitude towards mobile advertising (Johnson, 2013). Izquierdo-Yusta, Olarte-Pascual and Reinares-Lara (2012) studied the antecedents of attitude towards mobile advertising. The results were similar to those of Ünal and others (2011), which suggested that users perceive mobile advertising to 
be informative, entertaining, personalized, and reliable. Meanwhile, no attempt has been made previously to find intra-group perceptual differences among mobile device users.

Recent studies in the area of mobile advertising such as Lin, Hsu and Lin (2017) also regarded attitudes as major contributors in affecting consumers' behavior towards mobile advertising. The authors further added some of the major factors that affect consumers' attitudes such as irritation, credibility, and perceived usefulness of mobile advertising. Kavei (2015) also found that consumer attitude has a strong impact on the acceptance or rejection of mobile advertising. Lee and Kim (2017) explored the impact of consumers' ad-content preference on their attitude towards mobile advertising. The results of that study highlighted that perceived informative value and perceived entertainment value strongly mediate the effects of content preference on attitude towards mobile advertising. According to Ajzen (1989), attitudes are composed of various belief dimensions associated with economic and social factors. The authors further added that attitudes towards advertising are very complex in nature. Petrovici and others (2013) asserted that beliefs about advertising in general are antecedents of consumers' attitudes. But in most of the previous studies (Wang \& Sun, 2010) attitudes and beliefs are measured and used interchangeably. That is why attitudes and beliefs about mobile advertising are not differentiated in this study.

\subsection{Lifestyle segmentation}

An organization - in the form of reseller, government, industrial manufacturer, or consumer - cannot serve all its customers equally while operating in a particular market. This is because the customers might be too heterogeneous in their needs, or they can be widely scattered. There can be many submarkets in each heterogeneous market. The concept of market segmentation was first introduced by Smith (1956), who explained it as the process of dividing the whole market into various homogeneous groups having similar interests, desires, and needs. Since then, market segmentation has become a core concept in marketing campaigns and research. Several research studies that have been conducted examined different types of market segmentation, including demographic, geographic, behavioral, and consumer lifestyle segmentation. Consumer lifestyle segmentation is considered to be an extension of psychographic segmentation, which is based on the study of consumers' interests, opinions, and daily activities (Vyncke, 2002). Since the introduction of market segmentation in the 1960s, the study of consumer lifestyles has become an integral part of promotional management decisions as it provides more practical and accurate information to advertisers about consumers. Du, State, Brorsson and Avenesov (2016) emphasized the use of consumer profiling in areas such as marketing and advertising. They concluded in their research that the use of targeted and behavioral profiling of mobile device users helps in predicting their purchase patterns. Vyncke (2002) noted that lifestyle segmentation helps in classifying consumers into identifiable clusters having specific characteristics. In order to measure attitudinal and behavioral dimensions of consumers, Tai and Tam (1996) used activity, interests, and opinion scales in their research. Yang (2004) suggested that consumers' activities, interests, and opinions should be surveyed, as that would enable advertisers to better understand the needs of various market segments and increase the effectiveness of advertising campaigns. Meanwhile, Lamb, Hair and McDaniel (2012) pointed out that lifestyle segmentation can easily be misunderstood or incorrectly applied because it requires a large amount of data about consumers, making such research viable only for larger firms.

Some earlier studies (Park et al., 2001; Yang, 2004) also applied lifestyle segmentation for analyzing the relationship between consumer attitudes and effectiveness of Internet advertising. The research conducted by Park and others (2001) surveyed about 294 Internet users in their efforts to find the moderating effects of 
consumers' lifestyles on attitudes and the effectiveness of online advertising. In their study, the authors used 20 different statements to measure attitudes towards online advertising. At the same time, the effectiveness of online advertising was measured by the purchase intentions of respondents towards the advertised brands. In order to categorize the respondents into different lifestyle segments, the authors used 27 lifestyle related statements. In their analysis, the authors used these statements to form six factors: family-oriented person, considerable purchaser, conservative person, imitator, innovator, social person, and considerable purchaser with the help of factor analysis. Lifestyle segments were identified by applying a hierarchical cluster analysis approach. The results of their study highlighted significant relationships between consumers' lifestyles, attitude towards online advertising, and consumers' purchase intentions. Also, their research indicated that consumers' lifestyles affected their attitudes towards online advertising. For example, imitators were found to have complex attitudes towards online advertising, whereas the innovative segment positively predicted respondents' unique and informative attitudes towards online advertising. Furthermore, the remaining four segments also showed significant changes in attitude towards online advertising between lifestyle segments.

Yang (2004) conducted a study on Internet users in Taiwan. The study surveyed about 700 respondents by applying lifestyle segmentation, in which the respondents were categorized into three distinct lifestyle groups: self-indulgents, experiencers, and traditionalists. Yang (2004) used both the Ward method of hierarchical clustering and the K-mean cluster approach to find the clusters within the respondents. He used 36 items, categorizing them into six different dimensions (informativeness, materialism, good for consumers, hedonic, manipulative, and value distortion) to measure consumers' attitudes towards online advertising. The author adapted the lifestyle measurement scale of Tai and Tam (1996) and used about 30 statements having three dimensions (self-indulgents, expe- riencers, and traditionalists). In all of the items, the respondents were asked to provide their answers using a five-point Likert scale, ranging from strongly disagree (1) to strongly agree (5). The results of the study indicated that the three groups (self-indulgents, experiencers, and traditionalists) differed from one another in their attitudes towards online advertising. Yang (2004) suggested in his research to treat Internet users as a heterogeneous group.

In contrast to research conducted by Park and others (2001) and Yang (2004), the current study examined the effect of lifestyle segmentation on attitudes towards mobile advertising while also analyzing the relationship between lifestyle segments and the behavioral intentions of users. Vyncke (2002) argued that segmentation based on consumers' lifestyles has the ability to improve our understanding of consumers' attitudes towards advertising. The author further added that lifestyle segmentation can significantly contribute in making the advertising message more effective for different clusters of consumers.

\section{RESEARCH QUESTIONS}

Based on the extensive review of related literature, it is expected that lifestyle segmentation of mobile devices users has the capability to provide valuable information about consumers' attitudes towards mobile advertising. Furthermore, it can also identify some crucial aspects behind the behavioral intentions of mobile device users. Hence, the following research questions were formulated:

RQ1: What are the potential lifestyle segments of mobile device users?

RQ2: What are the characteristics of each of the identified segments of mobile device users?

RQ3: What are the statistical differences between each segment of mobile device users in terms of their attitudes towards mobile advertising?

RQ4: What are the statistical differences between each segment of mobile devices users in 
terms of their behavior towards mobile advertising?

RQ5: What is the impact of consumers' attitudes on their behavior towards mobile advertising?

\section{RESEARCH METHODOLOGY}

During the data collection phase, a survey method was adopted by providing mobile device users in Pakistan with an online questionnaire. Most of the previous studies also used survey methods for measuring consumer attitude towards advertising (Park et al., 2001; Yang, 2004). The same approach has been adopted by researchers who focused on online and mobile advertising (Merisavo et al., 2006; Wang \& Sun, 2010). This study used an online/ web-based questionnaire in place of a pencil-and-paper questionnaire. There are some crucial reasons behind the selection of an online questionnaire. First, Lefever, Dal and Matthíasdóttir (2007) argued that pencil-and-paper surveys are bound to time and location. For example, in the case of a classroom-administered questionnaire, the true willingness of the respondents is not guaranteed, whereas an online questionnaire allows the respondents to fill in the questionnaire at their own convenience (Wright, 2005). Furthermore, there is the extended ease of sending the responses in an online questionnaire, as the respondents share their opinion through the click of a button. There is no conclusive evidence in the literature that indicates the difference in responses between online surveys and pencil-and-paper / self-administrated surveys (Lefever et al., 2007). Meanwhile, Wright (2005) argued that Internet has the ability to provide easy access to individuals and groups who would be difficult to reach through other means. For example, some groups and communities, such as online stock traders and online shoppers, exist only in cyberspace. Such groups can be easily approached through online questionnaires (Wright, 2005).

\subsection{Instrument development}

The questionnaire comprised four major sections: demographics, lifestyle segmentation, attitudes towards mobile advertising, and consumers' behavioral intentions.

\subsubsection{Consumers' attitudes}

In order to measure consumers' attitudes towards mobile advertising, a 14-item scale was adapted from previous studies (Wang \& Sun, 2010). These 14 items were measured on a five-point Likert scale, ranging from 1 (strongly disagree) to 5 (strongly agree) in terms of the following five dimensions: informativeness, entertainment, credibility, economy, and value distortion.

\subsubsection{Lifestyle segmentation}

For measuring consumers' lifestyles, a list of 30 statements was used in which the respondents were asked to provide their answers on a fivepoint Likert scale, ranging from 1 (strongly disagree) to 5 (strongly agree). The use of activity, interest, and opinion statements has been popular in the area of market segmentation since the 1970s (Plummer, 1974). All of the statements related to activity, interest, and opinion were adapted from Tai and Tam (1996) and Yang (2004). Both of these studies were conducted on Asian consumers and are therefore relevant to the scope of the current study. Three different lifestyle segments - self-indulgents, experiencers, and traditionalists - were identified by their statements.

\subsubsection{Consumer behavior}

In the end, consumer behavior towards mobile advertising was measured by the frequency of ad-clicking and buying from the advertisers. The same approach was used by Zhang and Mao (2016) to assess consumer behavior towards mobile advertising.

The questionnaire was pre-tested among 15 mobile device users for the purpose of analyzing the usability of the statements. This was also done to see whether the respondents understand the questionnaire or not. It was found during the

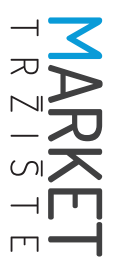


pre-testing process that the scale for measuring the consumers' lifestyles contained some statements which the respondents were either not responding to or to which they were neutral in their responses. Therefore, the number of statements was reduced to 25 in the final questionnaire.

\subsection{Sampling method}

The respondents of the study were recruited by following a convenience sampling method. The weblink of the questionnaire was put on different social and professional networking websites, such as Facebook, Linkedln, and Twitter. The questionnaire was available to the public for eight weeks, between 15 December 2016 and 15 February 2017. All the respondents were from Pakistan, as the country has made significant progress in the areas of e-commerce and the mobile market. According to the figures for March 2017 provided by the Pakistan Telecommunication Authority, there were about 139 million mobile phone subscribers, of whom 39 million had high-speed 3G/4G Internet connection on their devices (PTA, 2016). Shaheen, Lodhi, Mahmood and Abid (2017) also observed that mobile advertising would reach new heights in Pakistan in the years to come.

\subsection{Sample profiles}

There were 200 respondents participating in the survey, of whom 166 were regarded as valid. In this sample, $56 \%(n=93)$ were males, while $44 \%$ ( $n=73$ ) were females. In terms of the age of the respondents, about $36.2 \%(n=60)$ of the respondents were aged under 25 years, while $35.5 \%(n=59)$ were between 25 and 29 years of age. Overall, the number of younger respondents (aged between 12 and 29) made up about $71.9 \%(n=119)$ of the sample. For the sake of comparison, it should be pointed out that the percentage of younger respondents in studies conducted on the same topic in neighboring countries was $65 \%$ in Iran (Saadeghvaziri \& Hosseini, 2011) and $60 \%$ in India (Haq, 2012). In terms of the educational level of the respondents, some $72.9 \%(n=121)$ of the respondents had postgraduate degrees, another $21.7 \%(n=36)$ had bachelor's degrees, and $5.4 \%(n=9)$ had secondary school qualifications or lower education. There are strong demographic similarities with regard to education between this study and a number of other studies in the same area of research; namely, as Aslam, Batool and Haq (2016) this study has been conducted to investigate the consumer attitude towards SMS advertisement and its relationship with behavior. Entertainment, irritation, product involvement and appeal were used in order to investigate the attitude of the consumer. A questionnaire was used to examine the relationships among variables of the study. Overall 350 usable responses were gathered. SEM was used to obtain the results of the overall model. Results of the study indicate that 1 indicated in their research, $76.8 \%$ of the respondents had master's and doctoral degrees.

TABLE 1: Sample profiles

\begin{tabular}{|l|c|c|}
\hline Demographic Variables & $\begin{array}{c}\text { No. of } \\
\text { Cases }\end{array}$ & \% \\
\hline Gender & & \\
\hline Male & 93 & 56.0 \\
\hline Female & 73 & 44.0 \\
\hline Age & 60 & 36.2 \\
\hline Under 25 years old & 59 & 35.5 \\
\hline 25 to 29 years old & 34 & 20.5 \\
\hline 30 to 34 years old & 8 & 4.8 \\
\hline 35 to 39 years old & 5 & 3.0 \\
\hline 40 years old and above & & \\
\hline Education level & 9 & 5.4 \\
\hline Higher secondary or lower & 36 & 21.7 \\
\hline Bachelor's degree & 96 & 57.8 \\
\hline Master's degree & 25 & 15.1 \\
\hline Doctorate & & \\
\hline Income level (PKR) & 17 & 10.2 \\
\hline 20,000 or below & 23 & 13.9 \\
\hline 20,001 to 30,000 & 14 & 8.4 \\
\hline 30,001 to 40,000 & 14 & 8.4 \\
\hline 40,001 to 50,000 & 98 & 59.0 \\
\hline 50,000 or more & & \\
\hline
\end{tabular}


In terms of the income level of the sample, $24.1 \%(n=40)$ of the respondents had monthly incomes of PKR 30,000 or less, $16.8 \%(n=28)$ earned between PKR 30,000 and 50,000, and $59 \%(n=98)$ of the respondents had incomes of more than PKR 50,000. One reason for the greater percentage of higher income levels of the respondents was the percentage of respondents with higher levels of education, as $72.9 \%$ of the respondents had master's or doctoral degrees. The demographic profiles of the respondents are outlined in Table 1.

\section{RESULTS}

\subsection{Lifestyle segmentation}

All five research questions of this study focused on finding the lifestyle segments, the differentiated characteristics of each segment, and the impact of consumers' lifestyles on their attitude towards mobile advertising. At first, an exploratory factor analysis was applied to the data by using principle component analysis on all of the responses/statements related to consumers' lifestyle segments. This was done to examine potential lifestyle segmentation among mobile device users. Only those variables which have higher correlations with other variables were included in the factor analysis. This approach was suggested and used by Yang (2004). The factor analysis highlighted five factors whose factor loadings were greater than 0.5. In total, 20 out of 25 variables were heavily loaded. Tai and Tam (1996) proposed the use of scree tests and eigenvalues to decide on the number of factors to be retained. Scree tests highlighted a flat slope between the fourth and fifth factors. Furthermore, both of these factors had lower eigenvalues $(1.023,1.002)$, whereas the eigenvalues of the first three factors were 3.785, 2.895, and 1.968, respectively. For this kind of situations, Hair, Anderson, Tatham and Black (1998) suggested the exclusion of such factors, because they would not increase the explanatory power of the scale. In the end, three factors were kept, and the remaining two were excluded.
A cluster analysis was also applied on the three factors identified by the factor analysis. Previously, some researchers (Davis \& French, 1989) had questioned the validity and reliability of cluster analysis, but it is still commonly used in market segmentation in general and lifestyle segmentation in particular. In order to mitigate the problems of validity and reliability in cluster analysis, Yang (2004) suggested the use of two different cluster analysis approaches at the same time. Yang (2004) used Ward's method in hierarchical clustering and K-mean clustering approaches in his research. The same approach was applied in this study. Based on the dendrograms produced by Ward's method, three clusters were identified from the data. This was followed by using a K-mean clustering approach for the generation of clusters. As per the suggestion of Yang (2004), a one-way ANOVA was used to find significant differences among mobile device users according to their lifestyles.

The results highlighted three major lifestyle segments: self-indulgents, experiencers, and traditionalists (see Table 2). Self-indulgents accounted for $21 \%$ of the total sample size. The users from this lifestyle segment are prone to taking risks, self-centered, and hedonistic. Self-indulgents tend to strive for success. Experiencers, representing $24.7 \%$ of the sample, like novelty and variety. These users love to face new challenges, take risks, and seek variety/novelty in their lives. Experiencers tend to buy trendy and fashionable products and they also enjoy buying unique products. Traditionalists made up about $54.3 \%$ of the total sample. The users from this lifestyle segment are more traditional and less experimental. Traditionalists are more conventional and conforming and are also said to be opinion leaders within their social circles (Yang, 2004). These users are not risk takers and do not go for trendy or fashionable products. Traditionalists are least affected by advertisements of new products. 
TABLE 2: Lifestyle clusters

\begin{tabular}{|l|c|c|}
\hline Clusters & Cases & \% \\
\hline 1: Self-indulgent & 35 & 21.0 \\
\hline 2: Experiencer & 41 & 24.7 \\
\hline 3: Traditionalist & 90 & 54.3 \\
\hline
\end{tabular}

TABLE 3: Factor analysis of lifestyle variables

\begin{tabular}{|c|c|c|}
\hline Factor & Mean & Loading \\
\hline \multicolumn{3}{|l|}{ F1: Self-indulgent $(a=0.72)$} \\
\hline $\begin{array}{l}\text { When I like } \\
\text { something, I will buy } \\
\text { it without too much } \\
\text { deliberation. }\end{array}$ & 3.11 & 0.668 \\
\hline $\begin{array}{l}\text { I always do whatever } \\
\text { I feel like and } \\
\text { whenever I feel like it. }\end{array}$ & 3.34 & 0.526 \\
\hline $\begin{array}{l}\text { The sole purpose of } \\
\text { making money is to } \\
\text { spend it. }\end{array}$ & 2.93 & 0.637 \\
\hline $\begin{array}{l}\text { Sometimes I feel like } \\
\text { spending money } \\
\text { on anything I lay my } \\
\text { eyes on. }\end{array}$ & 2.95 & 0.676 \\
\hline $\begin{array}{l}\text { I often make impulse } \\
\text { purchases. }\end{array}$ & 2.82 & 0.690 \\
\hline \multicolumn{3}{|l|}{ F2: Experiencer $(a=0.71)$} \\
\hline $\begin{array}{l}\text { I always try something } \\
\text { new and unique. }\end{array}$ & 3.61 & 0.509 \\
\hline $\begin{array}{l}\text { I love fashionable and } \\
\text { trendy products. }\end{array}$ & 3.41 & 0.708 \\
\hline $\begin{array}{l}\text { It does not hurt to be } \\
\text { trendy if I feel like it. }\end{array}$ & 3.31 & 0.660 \\
\hline $\begin{array}{l}\text { I am often influenced } \\
\text { by advertisements of } \\
\text { new products. }\end{array}$ & 3.01 & 0.764 \\
\hline \multicolumn{3}{|l|}{ F3: Traditionalist ( $a=0.69$ ) } \\
\hline $\begin{array}{l}\text { I can easily influence } \\
\text { people around me } \\
\text { during conversation. }\end{array}$ & 3.34 & 0.617 \\
\hline $\begin{array}{l}\text { My friends often } \\
\text { consult me when } \\
\text { they cannot make up } \\
\text { their own mind. }\end{array}$ & 3.57 & 0.824 \\
\hline $\begin{array}{l}\text { I have a strong desire } \\
\text { to be successful. }\end{array}$ & 4.21 & 0.729 \\
\hline
\end{tabular}

Nunnally (1967) suggested that an instrument can be said to be reliable for a particular study when the Cronbach's a value is between 0.50 and 0.70 . The values of Cronbach's a for all three segments in this study are higher than the 0.50 standard proposed by Nunnally (1967), as can be seen in Table 3.

The differences in demographics among mobile device users with regard to their lifestyles were also examined (see Table 4). This is indicated by the results, which showed that there were significant differences in users' age, education, and income levels. Compared with self-indulgents, traditionalists and experiencers were younger. Traditionalists in particular were younger than the other two life segments, as $75.6 \%$ of them were less than 29 years old, whereas experiencers accounted for $70.8 \%$ and self-indulgents for $62.9 \%$ of the respondents. Furthermore, $24.4 \%$ of experiencers were in the age bracket of 30 to 34 years, which also included $20 \%$ of self-indulgents and $18.9 \%$ of traditionalists. While considering the educational level of respondents, it was found that experiencers had the highest level of education, as $75.6 \%$ had either master's or doctoral degrees. Self-indulgents were also highly educated, with $74.3 \%$ of them having postgraduate degrees. Similarly, $71.2 \%$ of the traditionalists were postgraduates. The analysis of income levels highlighted that traditionalists earned more than experiencers and self-indulgents: $73.4 \%$ of them were in the income bracket of PKR 50,000 or more, with $62.9 \%$ of self-indulgents and $58.6 \%$ of experiencers also found in the same bracket. 
TABLE 4: Profile of lifestyle clusters

\begin{tabular}{|l|c|c|c|c|c|c|}
\hline \multirow{2}{*}{ Variables } & \multicolumn{5}{|c|}{ Lifestyle clusters } \\
\cline { 2 - 6 } & \multicolumn{2}{|c|}{ Self-indulgents } & \multicolumn{2}{c|}{ Experiencers } & \multicolumn{2}{c|}{ Traditionalists } \\
\cline { 2 - 6 } & $\mathbf{N}$ & $\mathbf{\%}$ & $\mathbf{n}$ & $\mathbf{\%}$ & $\mathbf{n}$ & $\%$ \\
\hline Gender & & & & & & \\
\hline Male & 21 & 60.0 & 23 & 56.1 & 49 & 54.4 \\
\hline Female & 14 & 40.0 & 18 & 43.9 & 41 & 45.6 \\
\hline Age & & & & & & \\
\hline Under 25 years old & 10 & 28.6 & 17 & 41.5 & 33 & 36.7 \\
\hline 25 to 29 years old & 12 & 34.3 & 12 & 29.3 & 35 & 38.9 \\
\hline 30 to 34 years old & 7 & 20.0 & 10 & 24.4 & 17 & 18.9 \\
\hline 35 to 39 years old & 3 & 8.6 & 0 & 0 & 5 & 5.6 \\
\hline 40 years old and above & 3 & 8.6 & 2 & 4.9 & 0 & 0 \\
\hline Education Level & & & & & & \\
\hline Higher secondary or lower & 2 & 5.7 & 2 & 4.9 & 5 & 5.6 \\
\hline Bachelor's degree & 7 & 20.0 & 8 & 19.5 & 21 & 23.3 \\
\hline Master's degree & 18 & 51.4 & 28 & 68.3 & 50 & 55.6 \\
\hline Doctorate & 8 & 22.9 & 3 & 7.3 & 14 & 15.6 \\
\hline Income Level (PKR) & & & & & & \\
\hline 20,000 or below & 6 & 17.1 & 5 & 12.2 & 6 & 6.7 \\
\hline 20,001 to 30,000 & 3 & 8.6 & 7 & 17.1 & 13 & 14.4 \\
\hline 30,001 to 40,000 & 4 & 11.4 & 5 & 12.2 & 5 & 5.6 \\
\hline 40,001 to 50,000 & 5 & 14.3 & 2 & 4.9 & 7 & 7.8 \\
\hline 50,000 or more & 17 & 48.6 & 22 & 53.7 & 59 & 65.6 \\
\hline
\end{tabular}

\subsection{Attitude towards mobile advertising}

Fourteen statements were used for the analysis of attitude towards mobile advertising. The factor analysis highlighted five factors with eigenvalues greater than 1.0 that met the criteria set by Hair and others (1998) for retaining a particular factor. The Scree test of the eigenvalues also highlighted five factors. The Cronbach's a for each factor was reported at the same time (see
Table 4). All five factors had eigenvalues greater than 1.0 and a Cronbach's a greater than 0.5 . Thus, all of the five factors were retained. These factors were as follows: information (F1), entertainment (F2), credibility (F3), economy (F4), and value (F5). Two statements were used to analyze information ( $a=0.76$ ), four statements to analyze entertainment ( $a=0.72)$, three statements to analyze credibility ( $a=0.71)$, three statements to analyze economy $(a=0.75)$, and two statements to analyze value $(a=0.70)$. 
TABLE 5: Factor analysis of attitude variables

\begin{tabular}{|l|c|c|}
\hline Factor & Mean & Loading \\
\hline F1: Information $(a=0.76)$ & & \\
\hline Mobile advertising is good source of product/service information. & 3.49 & 0.724 \\
\hline Mobile advertising supplies relevant product information. & 3.66 & 0.748 \\
\hline F2: Entertainment $(a=0.72)$ & & \\
\hline Mobile advertising is entertaining. & 3.18 & 0.678 \\
\hline Mobile advertising is enjoyable. & 3.39 & 0.791 \\
\hline Mobile advertising is pleasing. & 3.70 & 0.894 \\
\hline Mobile advertising is interesting. & 3.80 & 0.589 \\
\hline F3: Credibility (a =0.71) & & \\
\hline Mobile advertising is credible. & 3.11 & 0.755 \\
\hline Mobile advertising is trustworthy. & 3.26 & 0.679 \\
\hline Mobile advertising is believable. & 3.39 & 0.821 \\
\hline F4: Economy (a =0.75) & & \\
\hline Mobile advertising has possible effects on economy. & 3.48 & 0.814 \\
\hline Mobile advertising raises our standard of living. & 3.19 & 0.768 \\
\hline Mobile advertising provides better product choices for consumers. & 3.41 & 0.592 \\
\hline F5: Value (a = 0.70) & & \\
\hline Mobile advertising promotes undesirable values in our society. & 3.17 & 0.745 \\
\hline Mobile advertising distorts the values of youth. & 3.35 & 0.879 \\
\hline
\end{tabular}

Yang (2004) pointed to the inability of demographic segmentation to find significant differences among Internet users in terms of their attitudes towards online advertising. The author found that the users have generally positive attitudes towards online advertising and did not find significant statistical differences by employing demographic segmentation. In order to analyze Yang's (2004) claims, a one-way ANOVA test was applied to the data to find any statistical differences among mobile device users in terms of their attitudes towards mobile advertising by employing demographic segmentation. The results in Table 6 show that there are no significant differences among mobile devices users in terms of their attitudes towards mobile advertising according to their gender, age, education, and income levels. It is evident from Table 6 that the $p$-values for each dimension are not significant (i.e. > than 0.05). That was the reason why lifestyle segmentation was selected for finding differences among various clusters of mobile device users.

TABLE 6: One-way ANOVA of consumers' demographics and attitude towards mobile advertising

\begin{tabular}{|l|c|c|c|c|c|c|c|c|}
\hline \multirow{2}{*}{ Dimensions } & \multicolumn{2}{|c|}{ Gender } & \multicolumn{2}{c|}{ Age } & \multicolumn{2}{c|}{ Education level } & \multicolumn{2}{c|}{ Income level } \\
\cline { 2 - 10 } & F-value & $\boldsymbol{p}$-value & F-value & $\boldsymbol{p}$-value & F-value & $\boldsymbol{p}$-value & F-value & $\boldsymbol{p}$-value \\
\hline Information & 1.513 & 0.221 & 3.79 & 0.876 & 1.588 & 0.194 & 0.536 & 0.71 \\
\hline Entertainment & 0.224 & 0.637 & 0.131 & 0.971 & 1 & 0.395 & 0.843 & 0.5 \\
\hline Credibility & 0.043 & 0.836 & 0.654 & 0.625 & 0.197 & 0.898 & 1.62 & 0.172 \\
\hline Economy & 0.991 & 0.321 & 1.147 & 0.336 & 0.667 & 0.573 & 0.872 & 0.482 \\
\hline Value & 1.19 & 0.277 & 0.425 & 0.79 & 1.243 & 0.296 & 2.42 & 0.461 \\
\hline
\end{tabular}


In order to find differences in attitude towards mobile advertising among lifestyle segments, a one-way ANOVA test was applied to the data. Yang (2004) suggested the use of a oneway ANOVA test to find statistical differences among different clusters. The results (see Table 7) highlighted significant statistical differences between lifestyle segments for three attitude dimensions: information ( $F=12.860$ and $p<$ 0.001), economy ( $F=9.296$ and $p<0.001)$, and value $(F=9.879$ and $p<0.001)$. consumer behavior was adapted from Zhang and Mao (2016). In order to find statistical differences for consumer behaviors among lifestyle segments, a one-way ANOVA test was applied to the data. The respondents were asked about their frequency of clicking and also about the number of times they bought a particular product advertised in mobile ads. The analysis highlighted significant differences among lifestyle segments (see Table 8) along two behavioral dimensions, namely, ad-clicking $(F=34.121$ and

TABLE 7: One-way ANOVA test of consumers' attitudes towards mobile advertising

\begin{tabular}{|l|c|c|c|c|c|}
\hline Dimensions & Self-Indulgents & Experiencers & Traditionalists & F-value & $\boldsymbol{p}$-value \\
\hline Information & 3.11 & 3.34 & 3.84 & 12.860 & .000 \\
\hline Entertainment & 3.54 & 3.49 & 3.50 & .078 & .925 \\
\hline Credibility & 3.20 & 3.27 & 3.26 & .085 & .919 \\
\hline Economy & 3.74 & 3.10 & 3.33 & 9.296 & .000 \\
\hline Value & 3.49 & 3.63 & 3.00 & 9.879 & .000 \\
\hline
\end{tabular}

\subsection{Consumer behavior towards mobile advertising}

Marketers and researchers have previously applied various tools to assess consumer behavior towards conventional advertisements, such as TV ads, billboards, magazine \& newspaper ads, and radio ads. Wang and Sun (2010) suggested the use of methods including ad traffic counts, sales effect, and field surveys for TV and radio advertisements. The assessment of consumer behavior became even more complex with the introduction of online and mobile advertising (Wang \& Sun, 2010). Zhang and Mao (2016) suggested that the frequency of ad-clicks and sales generated by a particular online/Internet ad should be counted. The scale for measuring $p<0.001)$ and buying advertised products $(F=$ 21.684 and $p<0.001)$.

\section{CONCLUSION}

The current study examined the relationship between mobile device users' lifestyle segments and their attitudes towards mobile advertising. Moreover, the relationship between consumer behavior and mobile device users' lifestyle segments was also analyzed. The limitations of demographic variables in predicting consumer behavior provided the reason for applying lifestyle segmentation to the study of mobile device users. The importance of consumer lifestyles has previously been highlighted

TABLE 8: One-way ANOVA test of consumer behavior towards mobile advertising

\begin{tabular}{|l|c|c|c|c|c|}
\hline Dimensions & $\begin{array}{c}\text { Self- } \\
\text { Indulgents }\end{array}$ & Experiencers & $\begin{array}{c}\text { Traditio- } \\
\text { nalists }\end{array}$ & F-value & $\boldsymbol{p}$-value \\
\hline Ad-clicking & 3.23 & 3.05 & 2.12 & 34.121 & .000 \\
\hline $\begin{array}{l}\text { Buying Advertised Product/ } \\
\text { Service }\end{array}$ & 3.03 & 2.83 & 2.09 & 21.684 & .000 \\
\hline
\end{tabular}


by various researchers in areas such as marketing and advertising. For example, Yang (2004) conducted a study on Taiwanese Internet users by employing lifestyle segmentation and found three lifestyle segments (namely, traditionalists, self-indulgents, and experiencers) among Taiwanese Internet users. Seounmi, Lee and Doyle (2003) also identified three personality types (variety seekers, risk takers, and innovators) in their research. Even though there is much interest in understanding consumer lifestyles and other psychographic profiles, few studies (Kim \& Lee, 2015) have analyzed the impact of consumer lifestyle segments on attitudes and behavior towards mobile advertising. Researchers' ability to better understand mobile device users' attitudes and behavioral patterns towards mobile advertising has been hindered by a failure to recognize the importance of lifestyle factors. In order to create more effective and targeted mobile advertising, mass customization of promotional activities is also required.

The current study supports the view that lifestyle segmentation can be helpful in targeting various segments of consumers according to their lifestyles. Furthermore, marketers can also design their promotional campaigns more effectively by using a lifestyle segmentation approach. In addition, the current study examined the relationships between consumer lifestyles and their attitudes and behaviors towards mobile advertising. Furthermore, attitudinal and behavioral differences between segments were also found. The overall results showed that traditionalists were less likely to click on or buy using mobile advertising. Moreover, traditionalists showed negative attitudes towards mobile advertising. Yang (2004) also found that traditionalists have negative attitudes towards online advertising, and the same was found in the current study. It is also important to mention that the three lifestyle segments (i.e. self-indulgents, experiencers, and traditionalists) did not all differ among them when respondents were asked about the credibility of mobile advertising and mobile ads as a source of entertainment. Surprisingly, all three lifestyle segments thought that mobile advertising is credible and agreed with the statement that mobile ads are entertaining. In order to gain a more thorough understanding of consumers' attitudes and behavior patterns towards mobile advertising, this study examined both positive and negative attitudes. In contrast to the study conducted by Yang (2004), the current study also tried to identify the behavioral outcomes of consumers from different lifestyle segments. Self-indulgents were found to be most likely to click on mobile advertising and also to be inspired by mobile ads. Finally, it can be concluded that lifestyle segmentation has the capability to predict consumers' attitudes and behavioral patterns towards mobile advertising.

\section{LIMITATIONS AND RECOMMENDATIONS FOR FUTURE RESEARCH}

Some of the limitations of the current study should be considered while evaluating the results. First, it is important to mention that the current study collected data by employing convenience sampling. According to Hair and others (1998), convenience sampling creates the problem of limited generalizability of findings. Although the questionnaires were sent to people from different backgrounds, the survey still failed to represent the total population. Future researchers should employ such sampling techniques in which the representation of the total population is ensured. Moreover, all the respondents in the current study come from a single country (Pakistan). Therefore, the results cannot be generalized to mobile device users of other countries. However, the results of the study can be useful in helping marketers understand mobile device users from countries such as India and Bangladesh. Furthermore, the lifestyle scales employed in this study were limited in nature and did not measure the lifestyle profiles of respondents in depth. This means that future researchers should develop a unique scale to gain a better understanding of consumers' lifestyles. 


\section{References}

1. Ajzen, I. (1989). Attitude structure and behavior. In: A. R. Pratkanis, S. J. Breckler \& A. G. Greenwald (eds.), Attitude structure and function (pp. 241-274). Boston, MA: Psychology Press.

2. Aslam, W., Batool, M., \& Haq, Z. U. (2016). Attitudes and Behavior of the Mobile Phones Users towards SMS Advertising: A Study in an Emerging Economy. Journal of Management Sciences, 3(1), 63-80.

3. Barutçu, S. (2007). Attitudes towards mobile marketing tools: A study of Turkish consumers. Journal of Targeting, Measurement and Analysis for Marketing, 16(1), 26-38.

4. Davis, B., \& French, W. A. (1989). Exploring advertising usage segments among the aged. Journal of Advertising Research, 29(1), 22-29.

5. Du, M., State, R., Brorsson, M., \& Avenesov, T. (2016). Behavior Profiling for Mobile Advertising. Paper presented at the 2016 IEEE/ACM $3^{\text {rd }}$ International Conference on Big Data Computing Applications and Technologies (BDCAT).

6. Ducoffe, R. H. (1996). Advertising Value and Advertising on the Web. Journal of Advertising Research, 36(5), 21-35.

7. Edwards, S. M., Li, H., \& Lee, J.-H. (2002). Forced Exposure and Psychological Reactance: Antecedents and Consequences of the Perceived Intrusiveness of Pop-Up Ads. Journal of Advertising, 31(3), 83-95.

8. Fazio, R. H. (1990). Multiple Processes by which Attitudes Guide Behavior: The Mode Model as an Integrative Framework. Advances in Experimental Social Psychology, 23, 75-109.

9. Fishbein, M., \& Raven, B. H. (1962). The AB Scales: An Operational Definition of Belief and Attitude. Human Relations, 15(1), 35-44.

10. Glasman, L. R., \& Albarracín, D. (2006). Forming attitudes that predict future behavior: A meta-analysis of the attitude-behavior relation. Psychological Bulletin, 132(5), 778-822.

11. González, A. M., \& Bello, L. (2002). The construct "lifestyle" in market segmentation: The behaviour of tourist consumers. European Journal of Marketing, 36(1/2), 51-85.

12. Hair, J. F., Anderson, R. E., Tatham, R. L., \& Black, W. C. (1998). Multivariate Data Analysis (5 $5^{\text {th }}$ ed.). New Jersey, NJ: Prentice-Hall, Inc.

13. Haq, Z. U. (2012). Attitude toward SMS Advertising: A Survey with Reference to Indian Consumers. Journal of Internet Commerce, 11(4), 271-290.

14. Izquierdo-Yusta, A., Olarte-Pascual, M. C., \& Reinares-Lara, E. M. (2012). Antecedents and Consequences of Attitude Toward Mobile Advertising: The Spanish Case Study. In: A. M. Gil-Lafuente, J. Gil-Lafuente \& J. M. Merigó-Lindahl (eds.), Soft Computing in Management and Business Economics: Volume 1 (pp. 297-312). Berlin: Springer.

15. Johnson, J. P. (2013). Targeted advertising and advertising avoidance. The RAND Journal of ECOnomics, 44(1), 128-144.

16. Jun, J. W., \& Lee, S. (2007). Mobile Media Use and its Impact on Consumer Attitudes towards Mobile Advertising. International Journal of Mobile Marketing, 2(1), 50-58.

17. Kavei, M. (2015). Factors influencing acceptance of mobile advertisement. Paper presented at the International Conference on modern researches in Management, Economics \& Accounting, Istanbul, Turkey.

18. Kim, K. Y., \& Lee, B. G. (2015). Marketing insights for mobile advertising and consumer segmentation in the cloud era: AQ-R hybrid methodology and practices. Technological Forecasting and Social Change, 91, 78-92.

19. Korgaonkar, P., Petrescu, M., \& Karson, E. (2015). Hispanic-Americans, Mobile Advertising and Mobile Services. Journal of Promotion Management, 21(1), 107-125. 
20. Kotler, P., \& Keller, K. L. (2015). Marketing Management. Boston, MA: Pearson Education.

21. Lamb, C. W., Hair, J. F., \& McDaniel, C. (2012). Marketing. New Jersey, NJ: Cengage Learning.

22. Lee, S., \& Kim, M. (2017). Who respond which cues in mobile advertising: Effects of image preference on the perceived value of and attitude towards mobile advertising. Advertising Research, $11(4), 42-67$.

23. Lefever, S., Dal, M., \& Matthíasdóttir, Á. (2007). Online data collection in academic research: advantages and limitations. British Journal of Educational Technology, 38(4), 574-582.

24. Lin, C-W., Hsu, Y-C., \& Lin, C-Y. (2017). User perception, intention, and attitude on mobile advertising. International Journal of Mobile Communications, 15(1), 104-117.

25. Merisavo, M., Kajalo, S., Karjaluoto, H., Virtanen, V., Salmenkivi, S., Raulas, M., \& Leppäniemi, M. (2007). An Empirical Study of the Drivers of Consumer Acceptance of Mobile Advertising. Journal of Interactive Advertising, 7(2), 41-50.

26. Merisavo, M., Vesanen, J., Arponen, A., Kajalo, S., \& Raulas, M. (2006). The effectiveness of targeted mobile advertising in selling mobile services: an empirical study. International Journal of Mobile Communications, 4(2), 119-127.

27. Nunnally, J. C. (1967). Psychometric theory. New York, NY: McGraw-Hill.

28. Okazaki, S., Molina, F. J., \& Hirose, M. (2012). Mobile advertising avoidance: exploring the role of ubiquity. Electronic Markets, 22(3), 169-183.

29. Park, J. Y., Kim, K. H., Ki, D. Y., \& Moon, H. I. (2001). Internet user lifestyle: its impact on effectiveness and attitude toward Internet advertising in Korea. Proceedings of the 2001 Annual Conference of the American Academy of Advertising, 19-23.

30. Parreño, J. M., Sanz-Blas, S., Ruiz-Mafé, C., \& Aldás-Manzano, J. (2013). Key factors of teenagers' mobile advertising acceptance. Industrial Management \& Data Systems, 113(5), 732-749.

31. Petrovici, D., Marinov, M., Paliwoda, S., \& Marinova, S. (2013). Determinants and antecedents of general attitudes towards advertising. European Journal of Marketing, 41(3), 307-326.

32. Plummer, J. T. (1974). The Concept and Application of Life Style Segmentation. Journal of Marketing, 38(1), 33-37.

33. PTA (2016). Telecom Indicators. Avaliable at: http://www.pta.gov.pk/index.php?ltemid=599

34. Saadeghvaziri, F., \& Hosseini, H. K. (2011). Mobile advertising: An investigation of factors creating positive attitude in Iranian customers. African Journal of Business Management, 5(2), 394-404.

35. Seounmi, Y., Lee, M., \& Doyle, K. O. (2003). Lifestyles of Online Gamers. Journal of Interactive Advertising, 3(2), 49-56.

36. Shaheen, M., Lodhi, R. N., Mahmood, Z., \& Abid, H. (2017). Factors Influencing Consumers' Attitude, Intention and Behavior Towards Short Message Service-Based Mobile Advertising in Pakistan. IUP Journal of Brand Management, 14(1), 24-44.

37. Sharma, C., Herzog, J., \& Melfi, V. (2008). Mobile Advertising: Supercharge Your Brand in the Exploding Wireless Market. Hoboken, NJ: John Wiley \& Sons.

38. Smith, W. R. (1956). Product Differentiation and Market Segmentation as Alternative Marketing Strategies. Journal of Marketing, 21(1), 3-8.

39. Statista (2016). Number of mobile phone users worldwide from 2013 to 2019 (in billions). Available at http://www.statista.com/statistics/274774/forecast-of-mobile-phone-users-worldwide/

40. Tai, S. H. C., \& Tam, J. L. M. (1996). A Comparative Study of Chinese Consumers in Asian Markets-A Lefestyle Analysis. Journal of International Consumer Marketing, 9(1), 25-42.

41. Terry, D. J., \& Hogg, M. A. (1996). Group Norms and the Attitude-Behavior Relationship: A Role for Group Identification. Personality and Social Psychology Bulletin, 22(8), 776-793.

42. Tsang, M. M., Ho, S-C., \& Liang, T-P. (2004). Consumer Attitudes Toward Mobile Advertising: An Empirical Study. International Journal of Electronic Commerce, 8(3), 65-78. 
43. Ünal, S., Ercis, A., \& Keser, E. (2011). Attitudes towards Mobile Advertising - A Research to Determine the Differences between the Attitudes of Youth and Adults. Procedia - Social and Behavioral Sciences, 24, 361-377.

44. Vyncke, P. (2002). Lifestyle Segmentation. European Journal of Communication, 17(4), 445-463.

45. Wang, Y., \& Sun, S. (2010). Assessing beliefs, attitudes, and behavioral responses toward online advertising in three countries. International Business Review, 19(4), 333-344.

46. Wright, K. B. (2005). Researching Internet-Based Populations: Advantages and Disadvantages of Online Survey Research, Online Questionnaire Authoring Software Packages, and Web Survey Services. Journal of Computer-Mediated Communication, 10(3), 00-00.

47. Yang, K. C. C. (2004). A comparison of attitudes towards Internet advertising among lifestyle segments in Taiwan. Journal of Marketing Communications, 10(3), 195-212.

48. Zhang, J., \& Mao, E. (2016). From Online Motivations to Ad Clicks and to Behavioral Intentions: An Empirical Study of Consumer Response to Social Media Advertising. Psychology \& Marketing, 33(3), 155-164. 